\title{
Chromosome stability, in the absence of apoptosis, is critical for suppression of tumorigenesis in $\operatorname{Tr} p 53$ mutant mice
}

\author{
Geng Liu ${ }^{1}$, John M Parant ${ }^{1}$, Gene Lang ${ }^{1}$, Patty Chau ${ }^{1}$, Arturo Chavez-Reyes ${ }^{1}$, Adel K El-Naggar ${ }^{2}$, Asha Multani ${ }^{1}$, \\ Sandy Chang ${ }^{1} \&$ Guillermina Lozano $^{1}$
}

The $\mathbf{p 5 3}$ protein integrates multiple upstream signals and functions as a tumor suppressor by activating distinct downstream genes ${ }^{1-3}$. At the cellular level, p53 induces apoptosis, cell cycle arrest and senescence. A rare mutant form of p53 with the amino acid substitution R175P, found in human tumors, is completely defective in initiating apoptosis but still induces cell cycle arrest ${ }^{4,5}$. To decipher the functional importance of these pathways in spontaneous tumorigenesis, we used homologous recombination to generate mice with mutant p53-R172P (the mouse equivalent of R175P in humans). Mice inheriting two copies of this mutation (Trp53515C/515C) escape the early onset of thymic lymphomas that characterize Trp53-null mice. At 7 months of age, $90 \%$ of Trp53-null mice had died, but $85 \%$ of $\operatorname{Trp} 53^{515 C / 515 C}$ mice were alive and tumor-free, indicating that p53-dependent apoptosis was not required for suppression of early onset of spontaneous tumors. The lymphomas and sarcomas that eventually developed in $\operatorname{Trp} 53^{515 C / 515 C}$ mice retained a diploid chromosome number, in sharp contrast to aneuploidy observed in tumors and cells from Trp53-null mice. The ability of mutant p53-R172P to induce a partial cell cycle arrest and retain chromosome stability are crucial for suppression of early onset tumorigenesis.

We introduced the $515 \mathrm{G} \rightarrow \mathrm{C}$ mutation into the $\operatorname{Tr} p 53$ locus by homologous recombination into embryonic stem (ES) cells and

Figure 1 Generation of $\operatorname{Trp} 53^{515 \mathrm{C} / 515 \mathrm{C}}$ mice. (a) The cre-loxP-mediated strategy used to generate the knock-in allele. Mice with an insertion of the gene neor flanked by two loxP sites in intron 4 of $\operatorname{Trp} 53$ and a missense mutation in exon 5 (asterisk) were generated and mated with $\mathrm{CMV}$-cre mice to delete the insertion and generate mice with only the targeted mutation (515C). (b) Southern-blot analysis of ES cells using probe A. +/+, wild-type ES cells; $+/$ neo, targeted ES cells with neor. (c) Southern-blot analysis of ES cells using probe B. The band of $3.3 \mathrm{~kb}$ corresponds to the Trp53 pseudogene (d) Western-blot analysis using an antibody to p53 on protein extracts from a wild-type (WT) MEF, two Trp53515C/515C (C/C) MEFs and a Trp53-1- MEF.
cre-loxP-mediated excision in mice (Fig. 1). Sequencing of the entire coding region of the Trp53 transcript from a homozygous mutant mouse found no other changes. The allele $\operatorname{Tr} p 53^{515 \mathrm{C}}$ expressed a fulllength mutant p53 protein with the amino acid substitution R172P, which was more abundant than wild-type p53 (Fig. 1d).

To assay the cell cycle arrest function, we treated subconfluent cultures of wild-type, $\operatorname{Tr} p 53$-null, and $\operatorname{Tr} p 53^{515 \mathrm{C} / 515 \mathrm{C}}$ mouse embryonic fibroblasts (MEFs) with $\gamma$-radiation and labeled them with 5-bromo-deoxyuridine (BrdU) to measure the number of cells in S phase ${ }^{6}$. The ratio of cells in S phase among cells treated with $\gamma$-radiation versus untreated cells was significantly lower in $\operatorname{Tr} p 53^{515 \mathrm{C} / 515 \mathrm{C}}$ MEFs than in Trp53-null MEFs (Fig. 2a), but the

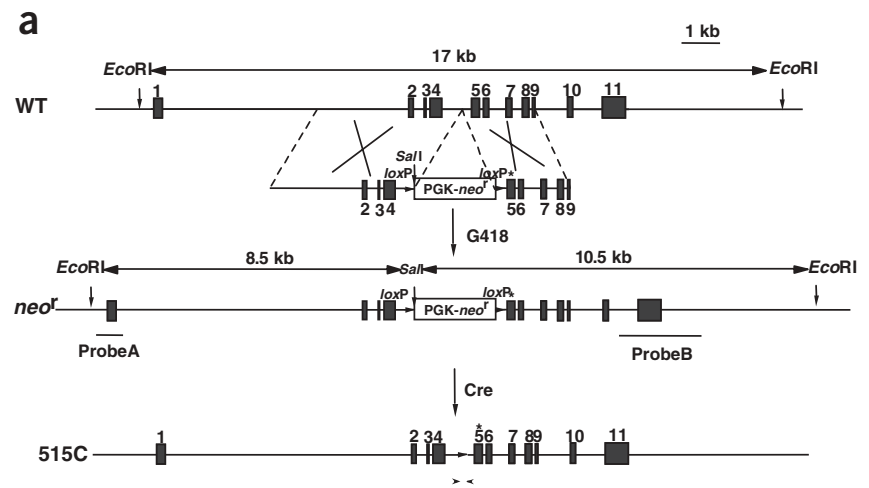

b

C
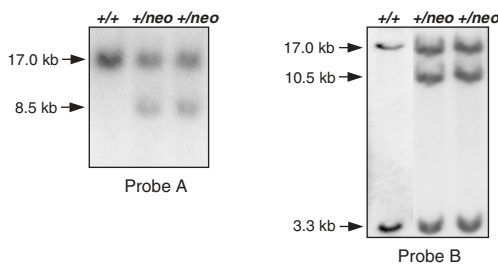

d

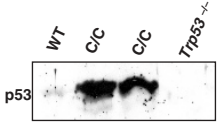

${ }^{1}$ Department of Molecular Genetics, Section of Cancer Genetics, and ${ }^{2}$ Department of Pathology, The University of Texas M.D. Anderson Cancer Center, 1515 Holcombe Blvd., Houston, Texas 77030, USA. Correspondence should be addressed to G.L. (gglozano@mdanderson.org). 


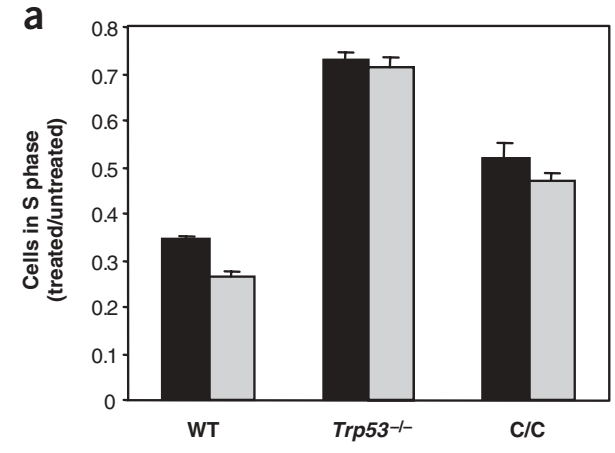

b

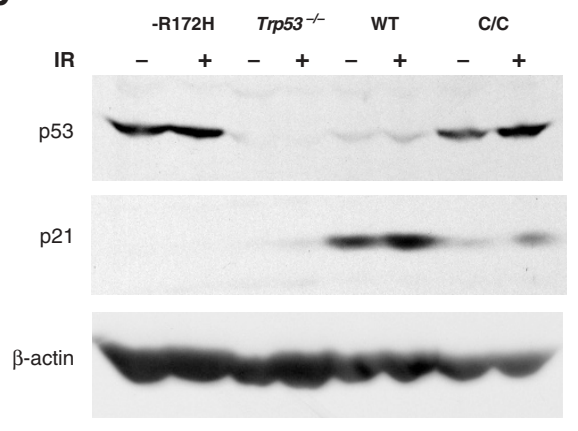

extent of cell cycle arrest was less than that in wild-type cells. Notably, endogenous p53-R172P was more abundant after $\gamma$-radiation, like wild-type p53, whereas the level of another p53 mutant protein, p53-R172H, did not change (Fig. 2b and data not shown). p53-R172P weakly induced Cdkn1a (encoding p21), a crucial target of p53 in cell cycle control ${ }^{7}$ (Fig. 2b). Thus, endogenous p53-R172P retained partial cell cycle checkpoint function in response to DNA damage by $\gamma$-radiation.
Figure $2 \operatorname{Trp5} 3^{515 \mathrm{C} / 515 \mathrm{C}}$ MEFs retained a partial cell cycle checkpoint after $\gamma$-radiation. (a) The ratio of cells in $\mathrm{S}$ phase among cells treated with $\gamma$-radiation at 6 Gy (black columns) and 10 Gy (gray columns) versus untreated cells was compared between wild-type (WT), Trp53 $3^{-1-}$ and $\operatorname{Trp} 53^{515 \mathrm{C} / 515 \mathrm{C}}$ (C/C) cells. (b) Wild-type (WT), Trp53-/- and Trp53515C/515C (C/C) MEFs and MEFs with two copies of mutant p53-R172H (R172H) were treated with 6 Gy of $\gamma$-radiation and subjected to western-blot analysis using antibodies to $\mathrm{p} 53, \mathrm{p} 21$ and $\beta$-actin.

To determine whether the p53-R172P mutant was defective in causing apoptosis, we used the adenovirus E1A oncoprotein to sensitize MEFs to p53-dependent apoptosis ${ }^{8}$. MEFs infected with a retrovirus expressing E1A were exposed to adriamycin or deprived of serum, conditions known to trigger p53-dependent apoptosis ${ }^{9}$. In contrast to wild-type MEFs, both $\operatorname{Tr} 553^{515 \mathrm{C} / 515 \mathrm{C}}$ and $\operatorname{Trp} 53$-null MEFs were equally resistant to apoptosis (Fig. $\mathbf{3 a}-\mathbf{c}$ ). These data indicate that the p53-R172P mutant did not induce apoptosis. To confirm this finding, we measured apoptosis in freshly isolated thymocytes after $\gamma$-radiation ${ }^{10,11}$. Wild-type thymocytes were highly sensitive to $\gamma$ radiation, whereas $\operatorname{Tr} p 53^{515 \mathrm{C} / 515 \mathrm{C}}$ and $\operatorname{Tr} p 53^{-1-}$ thymocytes were equally insensitive (Fig. 3d). Heterozygous $\operatorname{Tr} p 53^{+/ 515 \mathrm{C}}$ thymocytes had an intermediate response. All thymocytes were sensitive to p53independent apoptosis induced by dexamethasone (Fig. 3e), indicating that the $\operatorname{Tr} p 53^{515 \mathrm{C} / 515 \mathrm{C}}$ thymocytes had a specific apoptotic defect only in the p53-dependent DNA damage-response pathway. To further confirm that $\operatorname{Tr} p 53^{515 \mathrm{C} / 515 \mathrm{C}}$ mutants were unable to induce apoptosis in vivo, we irradiated 13.5-day-old embryos and analyzed p53-dependent apoptosis in the central nervous system. As expected, apoptosis was widespread in wild-type embryos but was not detected in the Trp53-null embryos ${ }^{12}$ or in $\operatorname{Tr} p 53^{515 \mathrm{C} / 515 \mathrm{C}}$ mutants (Fig. 3f). Therefore, the p53-R172P mutant did not induce p53-dependent apoptosis in response to DNA damage or oncogenic signaling.

Trp53-null mice succumb to early tumorigenesis, predominantly thymic lymphomas ${ }^{13,14}$. To determine whether the p53-
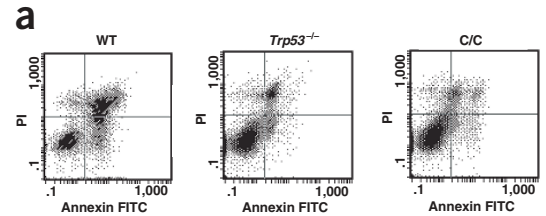

b

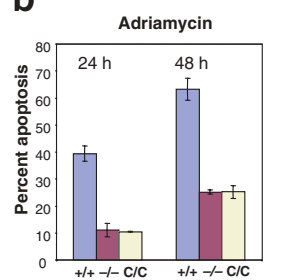

C

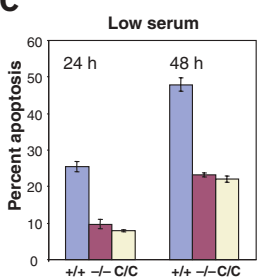

d

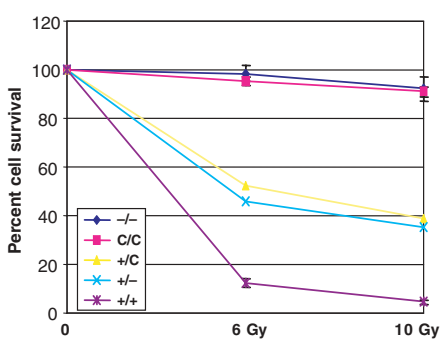

e
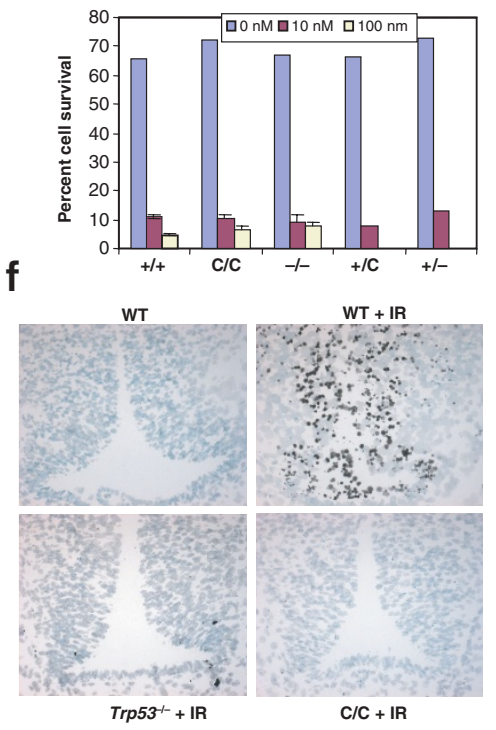

Figure 3 Trp53515c/515c cells lack p53dependent apoptosis. (a) Wild-type (WT), $\operatorname{Trp} 53^{-/-}$and $\operatorname{Trp} 53^{515 \mathrm{C} / 515 \mathrm{C}}$ (C/C) MEFs were infected with a retrovirus expressing $\mathrm{E} 1 \mathrm{~A}$ and treated with adriamycin. Apoptotic cells were measured with annexin $\mathrm{V}$ staining (annexin FITC) and FACS analysis. PI, propidium iodide. $(\mathbf{b}, \mathbf{c})$ E1A infected MEFs from wild-type $(+/+)$, $\operatorname{Trp53^{-/}}$ or $\operatorname{Trp} 53^{515 \mathrm{C} / 515 \mathrm{C}}$ (C/C) mice were treated with adriamycin or depleted of serum. Apoptotic cells were measured with annexin V staining and FACS analysis. (d) Thymocytes from wild-type (+/+), Trp53 $3^{+/-}, \operatorname{Trp} 53^{-1-}$, $\operatorname{Trp} 53^{515 \mathrm{C} / 515 \mathrm{C}}(\mathrm{C} / \mathrm{C})$ and $\operatorname{Trp} 53^{+/ 515 \mathrm{C}}(+/ \mathrm{C})$ mice were isolated and treated with 6 or 10 Gy of $\gamma$-radiation. Cell apoptosis and survival was measured by annexin $\mathrm{V}$ staining. (e) Thymocytes from wild-type $(+/+), \operatorname{Trp} 53^{-/-}, \operatorname{Tr} 553^{515 \mathrm{C} / 515 \mathrm{C}}$ $(\mathrm{C} / \mathrm{C}), \operatorname{Trp} 53^{+/ 515 \mathrm{C}}(+/ \mathrm{C})$ and $\operatorname{Trp} 53^{+/-}$mice were treated with dexamethasone and assayed with annexin $V$ staining. (f) Sections through the central nervous system of embryos at 13.5 days post-coitum were assayed for apoptosis. Untreated normal embryo is labeled WT. The remaining embryos were treated in utero with $\gamma$-radiation: wild-type (WT) $+\mathrm{IR}, \operatorname{Trp} 53^{-/-}+\mathrm{IR}$ and $\operatorname{Trp} 53^{515 \mathrm{C} / 515 \mathrm{C}}(\mathrm{C} / \mathrm{C})+\mathrm{IR}$. 
R172P mutant was able to suppress spontaneous tumorigenesis, we monitored tumor development in a cohort of $\operatorname{Trp} 53^{515 \mathrm{C} / 515 \mathrm{C}}$ Trp53-null and wild-type mice. $\operatorname{Tr} p 53^{515 \mathrm{C} / 515 \mathrm{C}}$ mice had substantially delayed tumor onset (Fig. 4a), and 39 of 40 mice remained tumor-free for 5 months. By 7 months of age, $90 \%$ of $\operatorname{Tr} p 53^{-1-}$ mice had succumbed to tumors, whereas $85 \%$ of $\operatorname{Tr} p 53^{515 \mathrm{C} / 515 \mathrm{C}}$ mice were still alive and tumor-free, clearly showing that the defect in $\operatorname{Trp} 53^{515 \mathrm{C} / 515 \mathrm{C}}$ mice is not equivalent to loss of $\operatorname{Tr} p 53$ in terms of tumorigenesis and survival. Tumors that arose in $\operatorname{Tr} p 53^{515 \mathrm{C} / 515 \mathrm{C}}$ mice between 7 and 13 months of age were composed of lymphomas and sarcomas (Fig. 4b-f). Eight of twenty-one mice (38\%) had highly disseminated lymphomas, only two of which were T-cell lymphomas. Most lymphomas were manifested in spleen and lymph nodes, and some stained positive for both CD4 and B-cell markers (Fig. 4h), suggesting that they arose from an early progenitor or histocytic cell. This was underscored by the high-grade histological analysis of these lymphomas. In sharp contrast, most tumors (75\%) in Trp53-null mice were thymic lymphomas that stained positive for both CD4 and CD8 (data not shown and ref. 15). Nine of twenty-one (43\%) $\operatorname{Trp} 53^{515 \mathrm{C} / 515 \mathrm{C}}$ mice had different types of high-grade sarcomas, including osteosarcomas (two), angiosarcomas (five) and rhabdomyosarcomas (two). Tumors were absent in two mice, and two

a
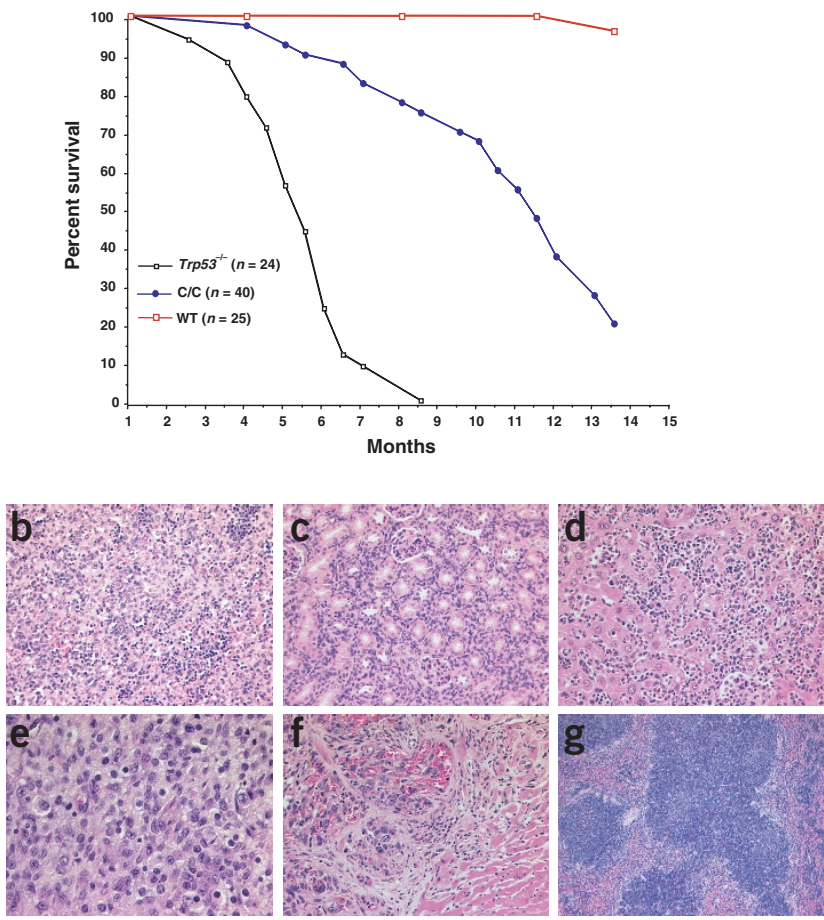

Figure 4 The $\operatorname{Trp} 53^{515 C / 515 \mathrm{C}}$ mutant suppresses early onset tumorigenesis. (a) Survival curves of a cohort of wild-type (WT), Trp53--- and $\operatorname{Trp53515C/515C}$ (C/C) mice. (b-g) Hematoxylin and eosin staining of tumors

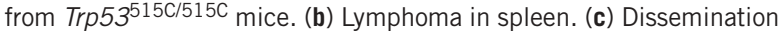
of lymphoma to kidney. (d) Dissemination of lymphoma to liver.

(e) Rhabdomyosarcoma. (f) Angiosarcoma in heart. (g) Atypical lymphoblastic hyperplasia in the spleen. (h) Staining with cell surface markers (CD4, CD8, IgM, B220) and flow cytometric analysis of a lymphoma from a $\operatorname{Trp53515C/515C}$ mouse. PE, phycoerythrin. (i) FACS analysis of tumor cell DNA content with tumor cells derived from $\operatorname{Trp} 53^{-1-}$ and $\operatorname{Trp} 53^{515 \mathrm{C} / 515 \mathrm{C}}$ (C/C) mice. PI, propidium iodide. (j) Karyotype analysis of a metaphase spread from

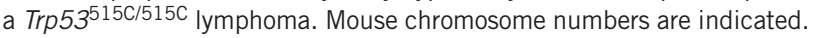

moribund mice showed only atypical hyperplasia (Fig. 4g). We observed atypical hyperplasia in the spleen in almost all $\operatorname{Trp} 53^{515 \mathrm{C} / 515 \mathrm{C}}$ mice with sarcomas. Two normal-looking $\operatorname{Trp53} 3^{515 \mathrm{C} / 515 \mathrm{C}}$ mice killed at 2 and 8 months of age also had atypical hyperplasia in the spleen. These data suggested that the early-onset tumors in Trp53-null mice and late-onset tumors in $\operatorname{Tr} p 53^{515 \mathrm{C} / 515 \mathrm{C}}$ mice arose through different mechanisms.

The rate of spontaneous apoptosis in both Trp53-null and $\operatorname{Trp53}{ }^{515 \mathrm{C} / 515 \mathrm{C}}$ lymphomas was extremely low ( $1.32 \pm 0.6$ and 0.18 \pm 0.04 percent apoptotic cells, respectively). Therefore, apoptosis cannot account for the prolonged latency of tumorigenesis in $\operatorname{Tr} p 53^{515 \mathrm{C} / 515 \mathrm{C}}$ mice. Trp53-null cells or tumors are aneuploid $^{16-19}$, and we postulated that the genomes of $\operatorname{Tr} p 53^{515 \mathrm{C} / 515 \mathrm{C}}$ tumors were more stable owing to their longer latency. Consistent with this hypothesis, eight of eight lymphomas (two of which were T-cell lymphomas) in $\operatorname{Tr} p 53^{515 \mathrm{C} / 515 \mathrm{C}}$ mice had either a diploid (six of eight) or tetraploid DNA content (two of eight; Fig. 4i and Table 1). On the other hand, all five Trp53-null lymphomas showed pronounced aneuploidy (Fig. 4i). Karyotype analysis of metaphase spreads from two $\operatorname{Tr} p 53^{515 \mathrm{C} / 515 \mathrm{C}}$ tumors confirmed the presence of 40 chromosomes without overt abnormalities (Fig. $4 j$ ). Notably, in some $\operatorname{Tr} p 53^{515 \mathrm{C} /-}$ mice, tumors that developed

h
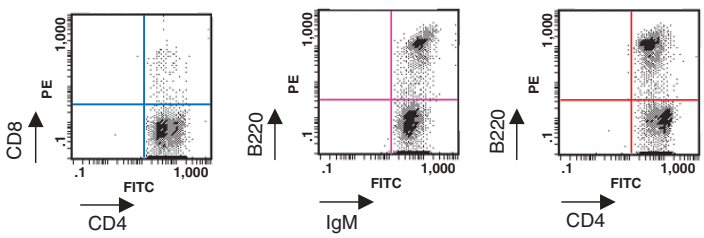

i
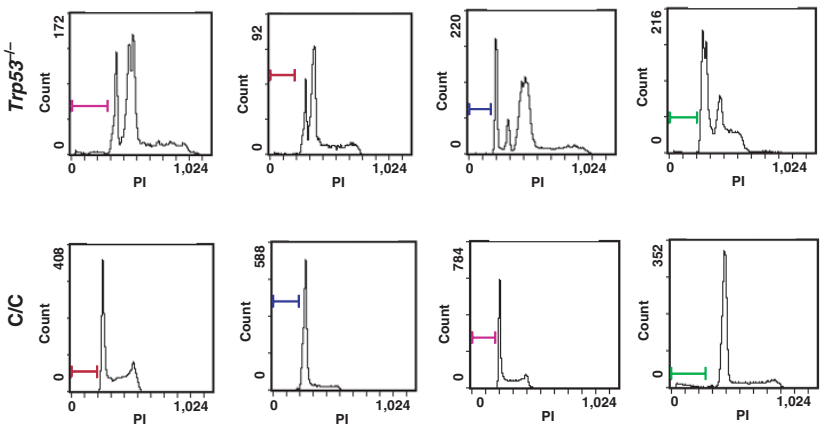

j

\begin{tabular}{|c|c|c|c|c|}
\hline 解 & $\frac{1}{3}$ & $\frac{A}{3}$ & ${ }_{4}{ }_{3}^{2}$ & $\frac{2}{5}$ \\
\hline$\frac{2}{8}$ & $B$ & 98 & $\hat{B}$ & E \\
\hline 6 & 7 & 8 & 9 & 10 \\
\hline $\begin{array}{ll}89 \\
11\end{array}$ & $\begin{array}{l}\frac{A}{2} \\
12\end{array}$ & 13 & 14 & $\begin{array}{l}3 \mathrm{f} \\
15\end{array}$ \\
\hline î & $\hat{i}$ & Af & 35 & 32 \\
\hline 16 & 17 & 18 & 19 & $\mathbf{X X}$ \\
\hline
\end{tabular}


Table 1 Ploidy in tumors of mice with different genotypes

\begin{tabular}{|c|c|c|c|c|}
\hline Mouse & Genotype & Tumor & Age of onset (months) & Ploidy \\
\hline 56 & $\operatorname{Trp} 53^{515 \mathrm{C} / 515 \mathrm{C}}$ & Thymic lymphoma a & 7 & Diploid \\
\hline 371 & $\operatorname{Trp} 53^{515 C / 515 c}$ & Thymic lymphoma & 7 & Tetraploid \\
\hline 31 & $\operatorname{Trp5} 53^{515 C / 515 \mathrm{C}}$ & Lymphoma/leukemia & 9 & Diploid \\
\hline 606 & $\operatorname{Trp} 53^{515 C / 515 c}$ & Large cell lymphoma & 10 & $\begin{array}{l}\text { Diploid (spleen) } \\
\text { Tetraploid (thymus) }\end{array}$ \\
\hline 552 & $\operatorname{Trp} 53^{515 C / 515 C}$ & Histocytic lymphoma & 10.5 & Diploid \\
\hline 38 & $\operatorname{Trp} 53^{515 \mathrm{C} / 515 \mathrm{C}}$ & Large cell lymphoma & 11 & Diploid \\
\hline 352 & $\operatorname{Trp} 53^{515 C / 515 \mathrm{C}}$ & Histocytic lymphoma & 12 & Diploid \\
\hline 538 & $\operatorname{Trp} 53^{515 C / 515 \mathrm{C}}$ & Histocytic lymphoma & 15.5 & Diploid \\
\hline 225 & $\operatorname{Trp5} 53^{515 \mathrm{Cl}-}$ & Thymic lymphoma & 5 & Aneuploid ${ }^{b}$ \\
\hline 105 & $\operatorname{Trp} 53^{515 \mathrm{C} /-}$ & Diffuse lymphoma & 5.5 & Aneuploid ${ }^{b}$ \\
\hline 150 & $\operatorname{Trp} 53^{515 \mathrm{C} /-}$ & Diffuse lymphoma & 7 & Aneuploid ${ }^{b}$ \\
\hline 151 & $\operatorname{Trp} 53^{515 \mathrm{C} /-}$ & Diffuse lymphoma & 7 & Aneuploid ${ }^{b}$ \\
\hline 505 & $\operatorname{Trp} 53^{515 \mathrm{C} /-}$ & Spleen lymphoma & 10 & Diploid \\
\hline 1 & $\operatorname{Trp} 53^{515 \mathrm{C} /-}$ & Histocytic lymphoma & 10.5 & Diploidc \\
\hline 90 & $\operatorname{Trp} 53^{-/-}$ & Thymic lymphoma & 3.5 & Aneuploidd \\
\hline 255 & $\operatorname{Trp} 53^{-1-}$ & Lymphomas involving spleen and lymph node & 3.5 & Aneuploid ${ }^{d}$ \\
\hline 288 & $\operatorname{Trp} 53^{-1-}$ & Thymic lymphoma involving spleen and lymph node & 4 & $\begin{array}{l}\text { Aneuploidd (spleen) } \\
\text { Aneuploid }^{\text {blymph node) }}\end{array}$ \\
\hline 229 & $\operatorname{Trp} 53^{-/-}$ & Thymic lymphoma & 5 & Aneuploidd \\
\hline 177 & $\operatorname{Trp} 53^{-/-}$ & Lymphoma/Leukemia & 7 & Aneuploid ${ }^{d}$ \\
\hline
\end{tabular}

aThis tumor was $\mathrm{CD} 4{ }^{+} \mathrm{CD} 8{ }^{+}$. ${ }^{\mathrm{b}}$ These samples had a single aneuploid peak by FACS analysis. ${ }^{\mathrm{C}}$ This sample had a minor aneuploid peak by FACS analysis. ${ }^{\mathrm{d}}$ These samples had multiple aneuploid peaks by FACS analysis.

early (at 5-7 months) were aneuploid whereas the two tumors that developed late (at 10 and 10.5 months) were diploid (Table 1). These data suggest a direct relationship between suppression of genome stability and onset of lymphomagenesis.

One of the mechanisms by which p53 suppresses aneuploidy is through proper control of centrosome duplication ${ }^{20}$. Trp53-null cells show centrosome hyperamplification, leading to multiple spindle poles and mis-segregation of chromosomes. We analyzed centrosome number in MEFs with an antibody to $\gamma$-tubulin. Similar to wild-type cells, $85 \%$ of $\operatorname{Trp} 53^{515 \mathrm{C} / 515 \mathrm{C}}$ MEFs in mitosis contained two centrosomes, whereas almost half of Trp53-null MEFs had more than three centrosomes (Fig. 5a,b). Karyotyping indicated that $\operatorname{Tr} p 53^{515 \mathrm{C} / 515 \mathrm{C}} \mathrm{MEFs}$ had substantially less variation in their chromosome number, most being $2 \mathrm{~N}, 4 \mathrm{~N}$ or $8 \mathrm{~N}$, than did Trp53-null cells (Fig. 5c,d). Most Trp53-null cells had extensive aneuploidy and considerably more chromosome abnormalities, including chromosome breaks and fragments, than did $\operatorname{Tr} p 53^{515 \mathrm{C} / 515 \mathrm{C}}$ cells (Fig. 5c,e). These results suggested that the p53-R172P protein is capable of suppressing genomic instability, especially chromosome gains and losses.

To distinguish between the roles of p53 in apoptosis and cell cycle arrest and in spontaneous tumorigenesis in vivo, we generated mice with a unique missense mutation in p53 (p53-R172P). Mice lacking $\operatorname{Tr} 553$ are susceptible to thymic lymphomas and sarcomas beginning at 3 months of age $\mathrm{e}^{13,14}$. The thymocyte is the primary cell type prone to tumorigenesis in Trp53-null mice, and it is extremely sensitive to p53-dependent apoptosis after genotoxic stress ${ }^{10,11}$. The delay in tumorigenesis in $\operatorname{Tr} p 53^{515 \mathrm{C} / 515 \mathrm{C}}$ homozygous mice is strong evidence that p53-dependent apoptosis is not the sole determinant of tumor suppression.

Genomic instability promotes tumorigenesis in multiple settings $^{21-23}$. Aneuploidy is prominent in Trp53-null thymic lymphomas and MEFs. Therefore, the propensity for genomic instability, especially aneuploidy, may be an important determinant for selection of oncogenic events in Trp53-null mice. Our studies indirectly suggest that the p53-dependent cell cycle checkpoint and ensuing genomic stability may have a role in delaying spontaneous tumorigenesis. Notably, the p53-R172P protein is able to efficiently suppress centrosome hyperamplification and chromosome gains and losses. Wildtype p53 suppresses centrosome abnormalities by inducing $C d k n 1 a$ and by a transcriptionally independent mechanism ${ }^{24}$. The p53-R172P protein, albeit at higher basal levels than normal, is capable of activating Cdkn1a. Therefore, the p53-dependent cell cycle checkpoint and the control of genomic stability might be linked. Genome stability may account for the delay in tumorigenesis in conversion of atypical hyperplasia seen in $\operatorname{Tr} p 53^{515 \mathrm{C} / 515 \mathrm{C}}$ mice at 2 months of age to pathologically confirmed tumors at 5-12 months. With time, owing to either lack of apoptosis or an incomplete cell cycle checkpoint in $\operatorname{Trp53} 515 \mathrm{C} / 515 \mathrm{C}$ cells, rare clones harboring oncogenic events may evolve, perhaps through other forms of genomic instability, such as translocations or gene amplification, that contribute to late tumorigenesis.

p53-dependent apoptosis is extremely important in controlling tumor progression in different models ${ }^{25,26}$. In our model, spontaneous tumorigenesis is assayed without a predisposing oncogenic mutation to examine the role of p53 in maintaining genomic stability. The late tumors that arose in $\operatorname{Tr} p 53^{515 \mathrm{C} / 515 \mathrm{C}}$ mice seemed very aggressive and fast-growing, consistent with the notion that once an appropriate oncogenic mutation occurs, tumor growth is greatly enhanced by deficiency in apoptosis. Therefore, although they suggest the importance of p53dependent cell cycle checkpoint and genome stability in spontaneous tumor suppression, our data do not detract from the role of apoptosis in tumor progression. These results support a multiple-step tumor-suppression mechanism used by $\mathrm{p} 53$ and help to explain a strong selection in human tumors for mutation of TP53 that cause deficiencies in cell cycle checkpoint control, genomic stability and induction of apoptosis ${ }^{1,2}$. Thus, p53 may serve as both a gatekeeper ${ }^{2}$ through its apoptotic function and a caretaker ${ }^{27}$ by maintaining genomic stability. 

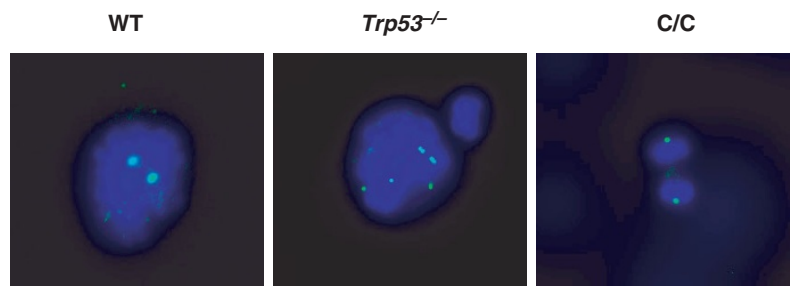

C
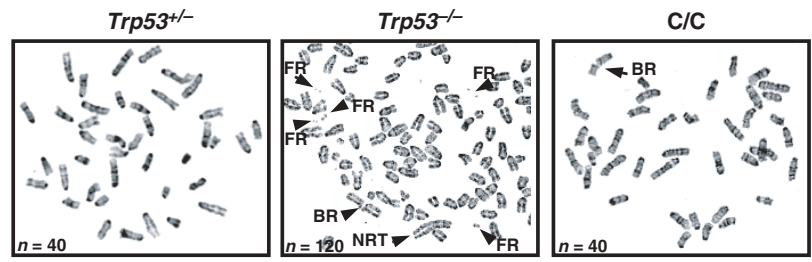

b

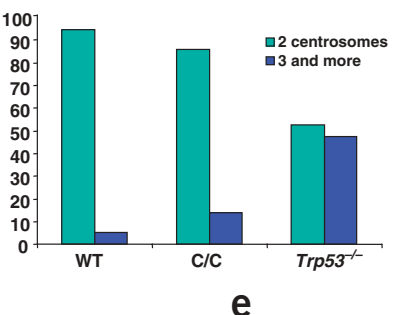

d

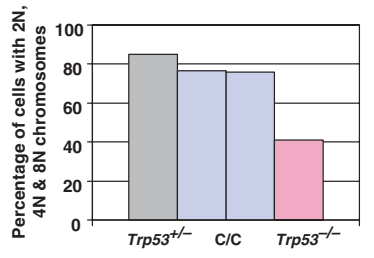

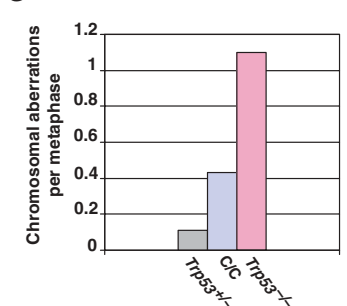

Figure $5 \operatorname{Trp5} 53^{515 C / 515 C}$ cells maintain chromosome stability. (a) Centrosomes were stained with antibody to $\gamma$-tubulin (green). Mitotic chromosomes were counterstained with DAPI (blue). WT, wild-type; C/C, Trp53515C/515C. (b) Quantification of centrosome number in wild-type (WT), Trp53515C/515C (C/C)

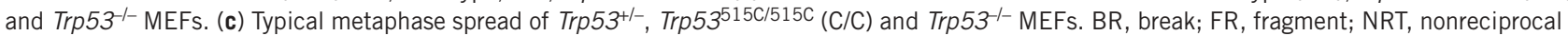
translocation. $n$, total chromosome number. (d) Chromosome number analysis in one $\operatorname{Trp} 53^{+/-}$, one $\operatorname{Trp} 53^{-/-}$and two $\operatorname{Trp} 53^{515 \mathrm{C} / 515 \mathrm{C}}$ (C/C) MEFs. (e) Chromosome aberrations in $\operatorname{Trp} 53^{+/-}, \operatorname{Trp} 53^{515 \mathrm{C} / 515 \mathrm{C}}(\mathrm{C} / \mathrm{C})$ and $\operatorname{Trp} 53^{-/-} \mathrm{MEFs}$.

\section{METHODS}

Generation of $\operatorname{Tr} p 53^{515 \mathrm{C} / 515 \mathrm{C}}$ mice. We cloned a PGK-neo ${ }^{\mathrm{r}}$ cassette flanked by two loxP sequences into the second AccI site of intron 4 of a Trp53 genomic fragment ${ }^{28}$. We generated the R172P substitution (CGC to CCC) at nucleotide 515 (taking the A in the first ATG as nucleotide number 1) in exon 5 of $\operatorname{Tr} p 53$ by site-directed mutagenesis. We crossed mice with germline transmission of the targeted allele to $C M V$-cre transgenic mice ${ }^{29}$ to effect germline deletion of the PGK-neo ${ }^{\mathrm{r}}$ cassette. We crossed the resulting mice with C57BL/6 mice to generate $\operatorname{Tr} p 53^{515 \mathrm{C} / 515 \mathrm{C}}$ mice. Primer sequences for genotyping by PCR are available on request.

Cell cycle analysis. We generated MEFs from 13.5-day-old embryos. For BrdU labeling experiments, we plated 5-7 $\times 10^{5}$ MEFs in $10-\mathrm{cm}$ plates $1 \mathrm{~d}$ before $\gamma$-radiation. We exposed cells to $\gamma$-radiation using a ${ }^{137} \mathrm{Cs}$ source. Fourteen hours after treatment, we added BrdU to the medium at a final concentration of $10 \mu \mathrm{M}$ for $4 \mathrm{~h}$. We fixed cells in $70 \%$ ethanol and stored them at $-20{ }^{\circ} \mathrm{C}$. We treated fixed cells with $0.04 \%$ pepsin and $2 \mathrm{~N} \mathrm{HCl}$ sequentially and then neutralized them with $0.1 \mathrm{M}$ sodium borate. Finally, we doubly stained cells with antibody to BrdU conjugated to fluorescein isothiocyanate (FITC) and with propidium iodide $\left(5 \mu \mathrm{g} \mathrm{ml}{ }^{-1}\right.$; Becton Dickinson) and subjected them to flow cytometric analysis.

Retroviral infection and apoptosis assays. We transfected phoenix packaging cells (P. Nolan; Stanford University School of Medicine) with either PWZL-hygro or PWZL-E1A12S (gifts from S. Lowe; Cold Spring Harbor Laboratory $)^{9}$. After $48 \mathrm{~h}$, we used the supernatants to infect MEFs in the presence of $8 \mu \mathrm{g} \mathrm{ml}^{-1}$ polybrene (Sigma) twice at 12-h intervals. We added hygromycin $\left(75 \mu \mathrm{g} \mathrm{ml}^{-1}\right.$; Roche) $24 \mathrm{~h}$ later. After $2-4 \mathrm{~d}$ of selection, we replated MEFs for apoptosis assays. We treated MEFs with $0.2 \mu \mathrm{g}$ $\mathrm{ml}^{-1}$ adriamycin (Sigma) or $0.1 \%$ fetal bovine serum for 24 and $48 \mathrm{~h}$. Cells in duplicate plates were trypsinized and pooled with floating cells. We measured apoptosis using the annexin-V assay (Clontech) with fluorescence-activated cell sorting (FACS) analysis or a trypan blue exclusion assay (a minimum of 200 cells were counted). Freshly isolated thymocytes from 1-month-old to 2-month-old mice were immediately treated with either $\gamma$-radiation or dexamethasone (Sigma). We carried out an annexin-V assay $16 \mathrm{~h}$ later. We normalized the survival rates of the cells after $\gamma$-radiation to survival rates for the same cell line without treatment. For the in vivo apoptosis assay, we treated pregnant females at 13.5 days post-coitus with 5 Gy $\gamma$-radiation and killed them $5 \mathrm{~h}$ later to collect embryos. Embryonic heads were fixed in phosphate-buffered formalin for 24 h. They were then processed, embedded and sectioned. We carried out TUNEL analysis on the slides using a modified protocol for the TdT FRAGEL kit from Oncogene Research. We fixed freshly isolated lymphoma cells from two Trp53-null mice and two $\operatorname{Tr} p 53^{515 \mathrm{C} / 515 \mathrm{C}}$ mice in $70 \%$ ethanol and measured spontaneous apoptosis by the sub-G1 fraction in a FACS analysis.

Western-blot analysis. We resuspended frozen MEF pellets in lysis buffer ${ }^{30}$ on ice for $1 \mathrm{~h}$. We loaded $40 \mu \mathrm{g}$ of protein on a $10 \%$ polyacrylamide gel. After transfer, we incubated the membranes with antibodies for p53 (CM5, Novocastra), p21 (C19, Santa Cruz) and $\beta$-actin (Sigma). We used antibody to rabbit conjugated to horseradish peroxidase (Amersham) and detected signals with an electrochemiluminescence kit (Amersham).

Tumorigenesis. The background of the $\operatorname{Tr} p 53^{515 \mathrm{C} / 515 \mathrm{C}}$ and $\operatorname{Trp} 53^{-/-}$mice ${ }^{14}$ was predominantly C57BL/6 with some $129 \mathrm{~Sv}$. To detect the ploidy of lymphomas, we separated tumor cells and fixed them with $70 \%$ ethanol. After staining them with propidium iodide (Sigma), we subjected the cells to FACS analysis. For cell surface marker analysis, we labeled lymphocytes with CD4FITC, CD8-phycoerythrin or IgM-FITC and B220-phycoerythrin (Becton Dickson) and subjected them to flow cytometric analysis.

Centrosome staining and chromosome analysis. We plated MEFs on coverslips and stained them with an antibody to $\gamma$-tubulin (Sigma) and secondary antibody conjugated to FITC as described ${ }^{24}$. We identified mitotic cells by DAPI staining. We counted the number of centrosomes in at least 50 cells in mitosis for each genotype under an epifluorescence microscope (Leika). We made chromosome preparations from the MEFs and freshly isolated lymphoma cells by the routine air-dried technique. We coded the slides for blind analysis, stained them with Giemsa for the analysis of chromosomal abnormalities and later decoded them to evaluate results.

\section{ACKNOWLEDGMENTS}

We thank S. Lowe and P. Nolan for reagents and K. Ramirez for assistance with FACS analysis. This work was supported by grants from the US National Cancer Institute and The Kadoorie Charitable Foundation.

\section{COMPETING INTERESTS STATEMENT}

The authors declare that they have no competing financial interests. 
Received 23 June; accepted 26 November 2003

Published online at http://www.nature.com/naturegenetics/

1. Ko, L.J. \& Prives, C. p53: puzzle and paradigm. Genes Dev. 10, 1054-1072 (1996).

2. Levine, A.J. p53, the cellular gatekeeper for growth and division. Cel/ 88, 323-331 (1997).

3. Vogelstein, B., Lane, D. \& Levine, A.J. Surfing the p53 network. Nature 408, 307-310 (2000).

4. Rowan, S. et al. Specific loss of apoptotic but not cell-cycle arrest function in a human tumor derived p53 mutant. EMBO J. 15, 827-838 (1996).

5. Ludwig, R.L., Bates, S. \& Vousden, K.H. Differential activation of target cellular promoters by 553 mutants with impaired apoptotic function. Mol. Cell. Biol. 16 4952-4960 (1996).

6. Deng, C., Zhang, P., Harper, J.W., Elledge, S.J. \& Leder, P. Mice lacking p21CIP1/WAF1 undergo normal development, but are defective in G1 checkpoint control. Cel/ 82, 675-684 (1995).

7. el-Deiry, W.S. et al. WAF1, a potential mediator of p53 tumor suppression. Cell 75, 817-825 (1993).

8. Lowe, S.W., Jacks, T., Housman, D.E. \& Ruley, H.E. Abrogation of oncogene-associated apoptosis allows transformation of p53-deficient cells. Proc. Natl. Acad. Sci. USA 91, 2026-2030 (1994).

9. Soengas, M.S. et al. Apaf-1 and caspase-9 in p53-dependent apoptosis and tumor inhibition. Science 284, 156-159 (1999).

10. Lowe, S.W., Schmitt, E.M., Smith, S.W., Osborne, B.A. \& Jacks, T. p53 is required for radiation-induced apoptosis in mouse thymocytes. Nature 362, 847-849 (1993).

11. Clarke, A.R. et al. Thymocyte apoptosis induced by p53-dependent and independent pathways [see comments]. Nature 362, 849-852 (1993).

12. Lee, Y., Chong, M.J. \& McKinnon, P.J. Ataxia telangiectasia mutated-dependent apoptosis after genotoxic stress in the developing nervous system is determined by cellular differentiation status. J. Neurosci. 21, 6687-6693 (2001).

13. Donehower, L.A. et al. Mice deficient for $p 53$ are developmentally normal but susceptible to spontaneous tumours. Nature 356, 215-221 (1992).

윽 14. Jacks, T. et al. Tumor spectrum analysis in p53-mutant mice. Curr. Biol. 4, 1-7 (1994).

15. Nacht, M. \& Jacks, T. V(D)J recombination is not required for the development of

lymphoma in Trp53-deficient mice. Cell Growth Differ. 9, 131-138 (1998).

16. Harvey, M. et al. In vitro growth characteristics of embryo fibroblasts isolated from p53-deficient mice. Oncogene 8, 2457-2467 (1993).

17. Venkatachalam, S. et al. Retention of wild-type Trp53 in tumors from $p 53$ heterozygous mice: reduction of $p 53$ dosage can promote cancer formation. EMBO J. 17, 4657-4667 (1998)

18. Liao, M.J. et al. No requirement for $\mathrm{V}(\mathrm{D}) \mathrm{J}$ recombination in $p 53$-deficient thymic lymphoma. Mol. Cell. Biol. 18, 3495-3501 (1998).

19. Hundley, J.E. et al. Increased tumor proliferation and genomic instability without decreased apoptosis in MMTV-ras mice deficient in p53. Mol. Cell. Biol. 17, 723-731 (1997).

20. Tarapore, P. \& Fukasawa, K. Loss of p53 and centrosome hyperamplification. Oncogene 21, 6234-6240 (2002).

21. TIsty, T.D. Regulation of genomic instability in preneoplastic cells. Cancer Surv. $\mathbf{2 8}$ 217-224 (1996).

22. Donehower, L.A. Genetic instability in animal tumorigenesis models. Cancer Surv. 29 , 329-352 (1997)

23. Lengauer, C., Kinzler, K.W. \& Vogelstein, B. Genetic instability in colorectal cancers. Nature 386, 623-627 (1997).

24. Tarapore, P., Horn, H.F., Tokuyama, Y. \& Fukasawa, K. Direct regulation of the centrosome duplication cycle by the p53-p21Waf1/Cip1 pathway. Oncogene 20, 3173-3184 (2001)

25. Schmitt, C.A. et al. Dissecting p53 tumor suppressor functions in vivo. Cancer Cel/ 1 289-298 (2002)

26. Symonds, H. et al. p53-dependent apoptosis suppresses tumor growth and progression in vivo. Cell 78, 703-711 (1994).

27. Kinzler, K.W. \& Vogelstein, B. Cancer-susceptibility genes. Gatekeepers and caretakers. Nature 386, 761-763 (1997).

28. Liu, G. et al. High metastatic potential in mice inheriting a targeted p53 missense mutation. Proc. Natl. Acad. Sci. USA 97, 4174-4179 (2000).

29. Lakso, M. et al. Targeted oncogene activation by site-specific recombination in transgenic mice. Proc. Natl. Acad. Sci. USA 89, 6232-6236 (1992).

30. Kapoor, M. \& Lozano, G. Functional activation of p53 via phosphorylation following DNA damage by UV but not gamma radiation. Proc. Natl. Acad. Sci. USA 95 2834-2837 (1998). 